\title{
CORRELATION BETWEEN ECCENTRIC TRAINING AND FUNCTIONAL TESTS IN SUBJECTS WITH RECONSTRUCTED ACL
}

\author{
CORRELAÇÃO ENTRE TREINO EXCÊNTRICO E TESTES FUNCIONAIS EM SUJEITOS COM \\ LCARECONSTRUÍDO
}

Original Article

ARTIGO ORIGINAL

Artículo Original

\section{CORRELACIÓN ENTRE ENTRENAMIENTO EXCÉNTRICO Y PRUEBAS FUNCIONALES EN SUJETOS CON LCA RECONSTRUIDO}

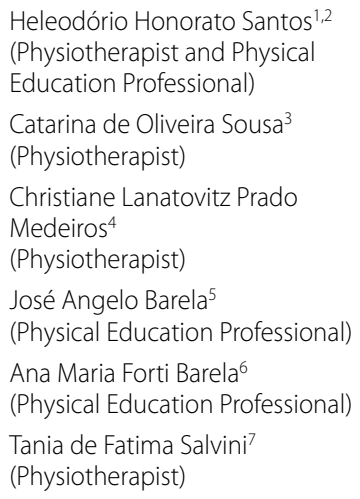

1. Universidade Federal da Paraíba (PAPGEF-UPE/UFPB), Associated

Physical Education Graduate Studies Program, João Pessoa, PB, Brazil. 2. Universidade Federal da Paraíba (UFPB), Department of Physiotherapy, João Pessoa, PB, Brazil.

3. Universidade Federal do Rio Grande do Norte (UFRN), Physiotherapy Graduate Studies Program, Natal, RN, Brazil.

4. Universidade Federal de São Carlos (UFSCar), Department of Physiotherapy, São Carlos, SP, Brazil. 5. Universidade Estadual Paulista Júlio de Mesquita Filho (Unesp), Department of Physical Education, Rio Claro, SP, Brazil.

6. Universidade Cruzeiro do Sul (Unicsul), Health Sciences Graduate Studies Program, São Paulo, SP, Brazil. 7. Universidade Federal de São Carlos (UFSCar), Physiotherapy Graduate Studies Program, São Carlos, SP, Brazil.

\section{Correspondence:}

Heleodório Honorato dos Santos

Av. Mons. Odilon Coutinho,

191/402, Cabo Branco, João Pessoa, PB, Brazil. 58045-120. dorioufpb@gmail.com

\begin{abstract}
Introduction: Eccentric training and jump tests are widely used to recover and measure deficits in knee strength and functionality after anterior cruciate ligament (ACL) reconstruction. Objective: To correlate knee extension and flexion torque generated by eccentric isokinetic training, with functional jump tests in subjects with reconstructed ACL. Method: Sixteen men with unilateral $A C L$ reconstruction were assessed before and after 12 weeks of eccentric isokinetic training of knee flexors and extensors ( $3 \times 10 \mathrm{MVC}, 2 \times /$ week) at 30\% $\mathrm{s}$ for extension and flexion torque (isometric; concentric and eccentric at 30 and 120\%s) and functional jump tests (single, triple, cross and figure of 8). Inter- and intra-limb pre- and post-training mean peak torque (MPT), distance and jump test times were compared along with the correlations between these variables, considering $P \leq 0.05$. Results: The affected limb (AL) showed significant gain of extension and flexion torque $(P<0.01)$ in the different test categories and velocities evaluated. In the non-affected limb (NAL), this only occurred in the eccentric category $(30$ and $120 \%$ s), in the extension $(P<0.01)$ and flexion $(P<0.05$ and $P<0.01)$ torques, respectively. In the jumps, there was an increase in distance (single and triple; $\mathrm{P}<0.05$ ) and a decrease in time (crossed and figure of $8 ; P<0.01$ ), however, MPT x Jump correlations were weak $(r<0.3)$ in the pre and post-training period in both limbs. Conclusion: Despite the gain in knee extension and flexion torque and jumping performance, the expected correlation was not satisfactory, suggesting that knee functionality involves other variables inherent to motor control. Level of Evidence IV; Type of study: Case series.
\end{abstract}

Keywords: Muscle strength; Performance tests; Rehabilitation.

\section{RESUMO}

Introdução: O treino excêntrico e testes de saltos são muito utilizados para recuperar e aferir déficits de força e funcionalidade do joelho, após reconstrução do ligamento cruzado anterior (LCA). Objetivo: Correlacionar o torque extensor eflexor do joelho, gerados pelo treino isocinético excêntrico, com testes funcionais de saltos em sujeitos com LCA reconstruído. Método: Foram avaliados 16 homens, com reconstrução unilateral do LCA, antes e depois de 12 semanas de treino isocinético excêntrico de extensores eflexores do joelho ( $3 \times 10$ CEVM, 2x/semana) a 30\%/s, quanto ao torque extensor e flexor (isométrico; concêntrico e excêntrico a 30\% s e 120\%) e aos testes funcionais de saltos (simples, triplo, cruzado e figura em 8). As médias dos picos de torque (MPT), a distância e os tempos dos testes de salto inter e intramembros, pré e pós-treino foram comparados, além das correlações entre essas variáveis, considerando $P \leq 0,05$. Resultados: O membro acometido (MA) mostrou ganho significativo de torque extensor eflexor $(P<0,01)$ nos modos e velocidades avaliados. No membro não acometido (MNA), isso ocorreu apenas para o modo excêntrico (30\%/s e 120\%/s), do torque extensor $(P<0,01)$ e flexor $(P<0,05$ e $P<0,01)$, respectivamente. Nos saltos, houve aumento da distância (simples e triplo; $P<0,05$ ) e diminuição do tempo (cruzado e figura em $8 ; P<0,01$ ), porém, as correlações entre MPT e saltos mostraram-se fracas nos dois membros $(r<0,3)$ antes e depois do treino. Conclusão: Apesar do ganho no torque extensor e flexor do joelho e no rendimento dos saltos, a correlação esperada não foi satisfatória, sugerindo que a funcionalidade do joelho envolve outras variáveis inerentes ao controle motor. Nível de evidência IV; Tipo de estudo: Série de casos.

Descritores: Força muscular; Provas de rendimento; Reabilitação.

\section{RESUMEN}

Introducción: El entrenamiento excéntrico y las pruebas de saltos son muy utilizados para recuperar y medir los déficits de fuerza y funcionalidad de la rodilla, después de la reconstrucción del ligamento cruzado anterior (LCA). Objetivo: Correlacionar el torque extensory flexor de la rodilla, generados por el entrenamiento isocinético excéntrico, con pruebas funcionales de saltos en sujetos con LCA reconstruido. Método: Fueron evaluados 16 hombres, con reconstrucción unilateral del $L C A$, antes y después de 12 semanas de entrenamiento isocinético excéntrico de extensores y flexores de la rodilla (3x10 CEVM, 2x/semana) a 30\%/s, cuanto al torque extensor y flexor (isométrico, concéntrico y excéntrico a 30 y $120 \%$ s) y a las pruebas funcionales de saltos (simple, triple, cruzado y figura en 8). Se compararon promedios de los picos de torque (MPT), distancia y tiempos de las pruebas de salto, inter e intra-miembros, prey 
post-entrenamiento, además de las correlaciones entre estas variables, considerando $P \leq 0,05$. Resultados: El miembro acometido (MA) mostró aumento significativo del torque extensor y flexor $(P<0,01)$ en los modos y velocidades evaluados. En el miembro no acometido (MNA), eso ocurrió sólo para el modo excéntrico (30 y 120\%/s), del torque extensor $(P<0,01)$ y flexor $(P<0,05$ y $P<0,01)$, respectivamente. En los saltos, hubo aumento en la distancia (simple y triple; $P<0,05)$ y disminución del tiempo (cruzado y figura en $8 ; P<0,01$ ), sin embargo, las correlaciones MPT x saltos se mostraron débiles $(r<0,3)$ en el pre y post-entrenamiento, en los dos miembros. Conclusión: A pesar del aumento en el torque extensory flexor de la rodilla y en el rendimiento de los saltos, la correlación esperada no fue satisfactoria, sugiriendo que la funcionalidad de la rodilla involucra otras variables inherentes al control motor. Nivel de evidencia IV; Tipo de estudio: Serie de casos

Descriptores: Fuerza muscular; Pruebas de rendimiento; Rehabilitación.

\section{INTRODUCTION}

Both ACL injury and reconstruction promote decreased trophism and strength of the knee extensor apparatus ${ }^{1}$, which may remain for to up seven years ${ }^{2}$. Eccentric training can trigger key morphological changes in thigh muscles during post-surgical ACL rehabilitation ${ }^{3}$.

Recently, in addition to isokinetic tests used to evaluate the knee joint torque, hop tests are considered good indicators of the combined knee joint and lower limb function because acceleration, deceleration and thrust movements are performed in sports ${ }^{3-8}$.

Although hop tests provide safety and efficiency parameters ${ }^{8}$ and are considered fairly reliable (>80\%) and sensitive (>82\%), their correlation with knee extensor and flexor torque is still controversial ${ }^{9,10}$. This study aimed to correlate possible gains in knee extensor and flexor torque generated by eccentric isokinetic training with some types of long jumps in subjects with reconstructed ACLs, given the hypothesis that knee extensor and flexor strengthening should improve the performance of functional hop tests.

\section{METHOD}

\section{Sample}

Of the 54 eligible subjects in this study, 40 were evaluated for compliance with the following inclusion criteria: 20 to 50 years; BMl $\leq 28 \mathrm{~kg} /$ $\mathrm{m}^{2}$; unilateral $A C L$ reconstruction; patellar tendon graft; two and five years post-reconstruction; post-operative rehabilitation $\geq$ six months; without knee pain or edema; having resumed the practice of sports; and availability to participate in the study.

After conducting the initial evaluations (dynamometry and functional hop tests) and training protocol, so 16 subjects (30.6 \pm 9.3 years; 78.1 \pm 12.1 $\mathrm{kg} ; 1.75 \pm 0.1 \mathrm{~m} ; \mathrm{BMl}=25.5 \pm 3.0 \mathrm{~kg} / \mathrm{m}^{2}$; injury time=50.4 \pm 34.9 months; surgery time $=27.0 \pm 23.7$ months) completed the study.

Sample size was determined by software $\mathrm{G}^{*}$ Power 3.1.0 adopting a power of 0.8 , considering $5 \%$ level of significance, 0.5 coefficient of correlation, and a 0.5 size effect, based on a pilot study ${ }^{11}$ and 16 subjects was computed with size sufficed to provide $81.7 \%$ statistical power. (Figure 1)

The study was approved by the Research Ethics Committee of the Federal University of São Carlos (REC/UFSCar Opinion n. 350/2006), and all subjects freely signed an Informed Consent Form, according to Resolution 196/96 of the National Health Council.

\section{Dynamometry}

Knee extensor and flexor torque were evaluated using an isokinetic dynamometer (Biodex Multi-Joint System 3, Shirley, NY-USA) 72 hours pre- and post-isokinetic training, and all subjects were evaluated by the same examiner, always starting with the non-affected limb (NAL) followed by the affected limb (AL) ${ }^{3}$ : 1) isometric; 2) concentric; and 3) eccentric test at 30 and $120 \%$ s.

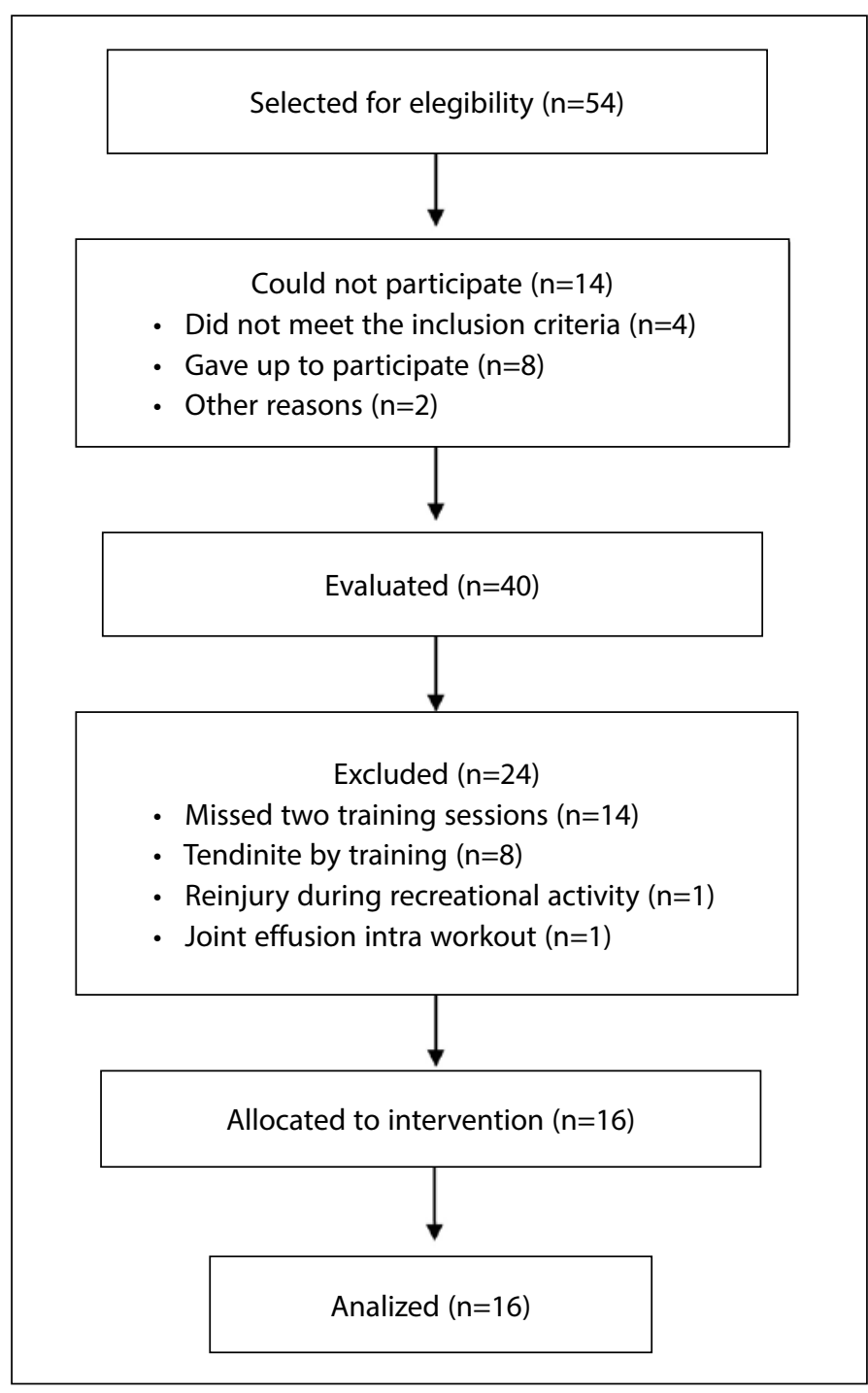

Figure 1. Sample flowchart.

After five minutes of warm-up on an bicycle at $20 \mathrm{~km} / \mathrm{h}(75 \mathrm{~W})^{6}$ and then, the subjects sat on the isokinetic dynamometer with trunk and knees flexed at 85 and $90^{\circ}$, respectively, with the trunk, pelvis and distal aspect of the thigh stabilized by straps.

The test consisted of three maximal voluntary isometric contractions (MVIC) of five seconds, with one minute interval between them ${ }^{6}$ at $60^{\circ}$ for extensors and $30^{\circ}$ for flexors. Concentric and eccentric tests $\left(30^{\circ} / \mathrm{s}\right.$ and $120 \%$ s) consisted of five consecutive maximal voluntary contractions (MVC), with three minutes rest between tests and calculated the MPT in each test ${ }^{6}$. 


\section{Functional tests}

A total of 72 hours after the isokinetic evaluations (pre- and post-training), the subjects performed five minutes warm-up, running at low speed followed by four hop tests: single/SH, triple/TH), crossover/ $\mathrm{CH}$ and Figure-8 hops/F8H.

In the SH and TH (Figures 2.1; 2.2), the distance covered using the same foot was measured from the starting to the landing point (heel) ${ }^{3}$. In the $\mathrm{CH}$, the subjects hopped over six meters $x 15 \mathrm{~cm}$ straight line from one side to the other (Figure 2.3), using the same foot ${ }^{12}$. In the F8H, there were two rows of three cones each, with one meter between the cones and five meters between the rows (Figure 2.4) and they completed a circuit hopping around both rows, in the shape of the number eight ${ }^{4}$. The time spent (in seconds) to complete the whole circuit was clocked in both the $\mathrm{CH}$ and $\mathrm{F}_{8} \mathrm{H}^{3}$.

The horizontal thrust tests were performed in the same order $(\mathrm{SH}$, $\mathrm{TH}, \mathrm{CH}$ and $\mathrm{F} 8 \mathrm{H}$ ) and starting with the $\mathrm{NAL}$, similarly to the torque evaluations ${ }^{12}$, pre- and post-training

\section{Isokinetic training}

After warm-up, the subjects completed an eccentric isokinetic training program, exclusively using the $\mathrm{AL}$, at $30^{\circ} / \mathrm{s}$ ( $3 \times 10 \mathrm{MVEC}$; interval between sets: three minutes; interval between sessions: 48 hours; frequency: 2x/week; duration: 12 weeks) for knee flexors and extensors ${ }^{3}$. Only, the subjects performed normal ADLs, including their recreational activities. The same physiotherapist guided the training to maintain a uniform exposure to verbal commands during the 24 sessions.

\section{Data analysis}

Statistical procedures were performed in the SPSS (20.0) using the Shapiro-Wilk, Student's t (paired and independent) and Pearson's correlation test. The following data were compared: 1) MPT; 2) time and hop distance means between the AL and NAL; and 3) MPT versus hop tests correlations for each limb in the pre- and post-training. The classification adopted for the correlation analysis was according Albuquerque et al. ${ }^{13}$, considering a 5\% significance level for all comparisons.

\section{RESULTS}

\section{Isokinetic dynamometry}

In the pre-training evaluation, the inter-limb comparison of knee extensor MPT showed a deficit in the AL in the: isometric (14\%; $P<0.01$ ), concentric at $30 \%$ s (19\%; $P<0.01)$, and $120 \%$ s (14\%; $P<0.05)$ and eccentric at $30 \%$ s $(10 \% ; P<0.01)$.

In the post-training, except in the eccentric mode at $30 \% \mathrm{~s}(\mathrm{P}=0.42)$, deficits were still observed (isometric $=9 \%, P<0.05$; concentric at $30 \%$ $s=11 \%, P<0.01$; concentric at $120 \% s=13 \%, P<0.01$; and eccentric at $120 \%$ $s=15 \%, P<0.01)$. The knee flexors showed a $14 \%$ and $10 \%$ increase in the AL compared with the NAL in the eccentric mode at 30 and $120 \% \mathrm{~s}$ $(P<0.01)$, respectively.

There was 9\% gain in the isometric $(P<0.05)$ and concentric modes at $30 \% \mathrm{~s}(\mathrm{P}<0.01) ; 7 \%$ in the concentric at $120 \% \mathrm{~s}(\mathrm{P}<0.05)$ and $19 \%$ in the eccentric mode at $30 \% \mathrm{~s}(\mathrm{P}<0.01)$ of the $\mathrm{AL}$, and $13 \%$ and $19 \%$ in the eccentric mode at 30 and $120 \%$ s $(P<0.01)$, respectively, of the $N A L$, when comparing the pre- and post-training (intra-limb) knee extensor MPT.

Gains also occurred in the: isometric mode (11\%; $P<0.01)$, concentric mode at $30 \%$ s $(10 \% ; \mathrm{P}<0.01)$, eccentric mode at $30 \%$ s $(24 \% ; \mathrm{P}<0.01)$ and at $120 \% \mathrm{~s}(19 \% ; \mathrm{P}<0.01)$ of the $\mathrm{AL}$. There were $9 \%$ and $11 \%$ gains in the eccentric mode at $30 \% \mathrm{~s}(P<0.05)$ and $120 \% \mathrm{~s}(P<0.01)$, respectively, of the NAL in the knee flexors.

Comparing the MPT of NAL extensors pre- versus the AL post-training, an $11 \%$ deficit $(P<0.05)$ occurred in the concentric mode at $30 \%$, and a $10 \%$ increase $(P<0.01)$ in the eccentric mode at $30 \%$ s (Table 1 ).

A widespread and significant increase (isometric: $7 \%, P<0.05$; concentric at 120\% $\mathrm{s}$ : 9\%, $\mathrm{P}<0.05$; eccentric at $30 \%$ s: $21 \%, \mathrm{P}<0.01$; and eccentric at $120 \% \mathrm{~s}$ : $20 \%, \mathrm{P}<0.01$ ) of the knee flexors occurred when comparing with the extensors, which surpassed the pre-training values of the NAL.

\section{Functional tests}

Three hop tests $(\mathrm{SH}, \mathrm{TH}$ and $\mathrm{F} 8 \mathrm{H})$ showed a significant increase $(P<0.01, P<0.01$ and $P<0.05$, respectively) in the pre-training period (Table 2), whereas only the $\mathrm{SH}$ and $\mathrm{TH}$ showed improved performance $(P<0.01)$ in the post-training, in the inter-limb comparison.

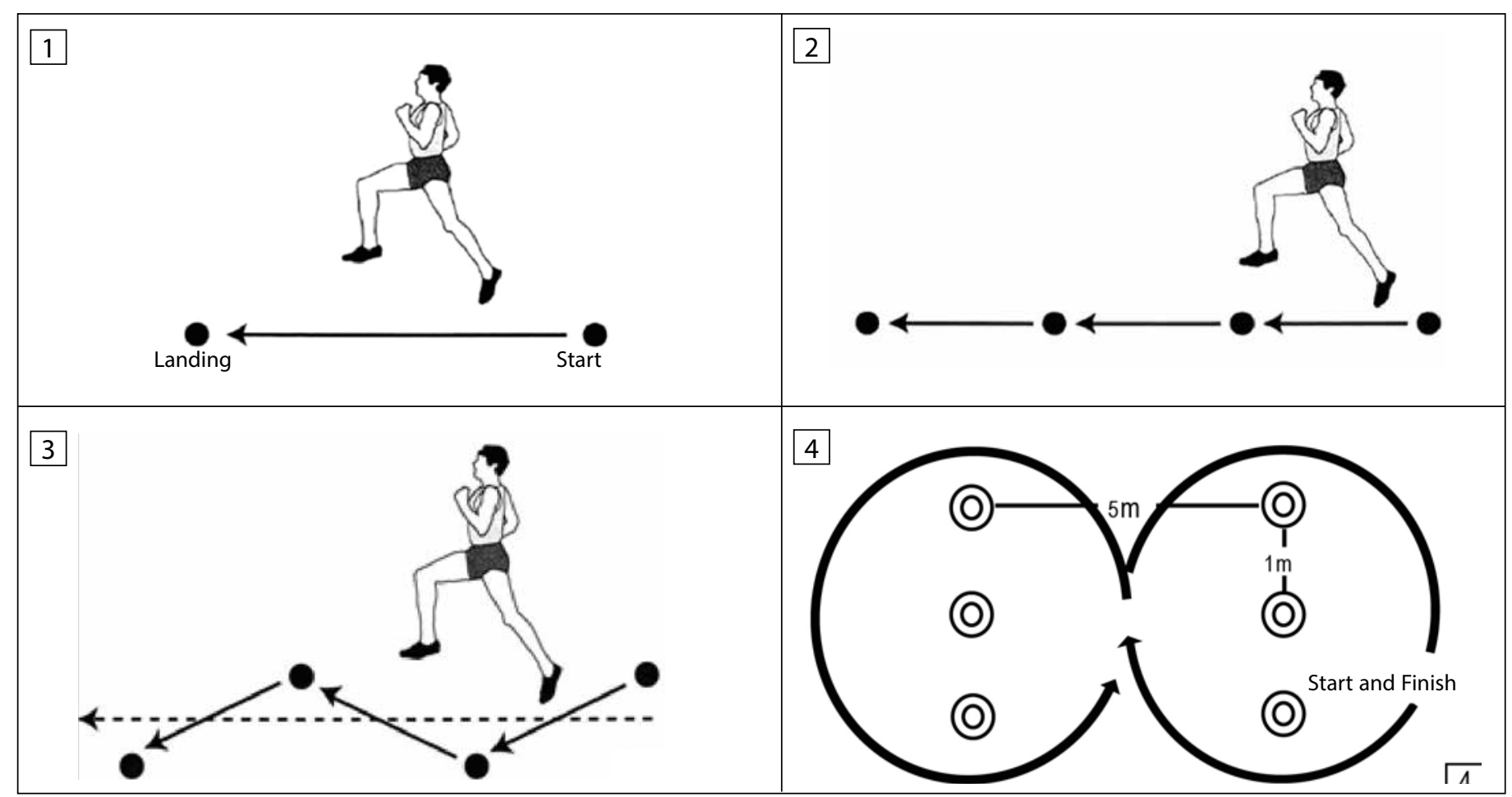

Figure 2. Functional tests: single hop (1); triple hop (2); crossover hop (3); figure-8 hop (4). 
Table 1. Comparisons of PTA (Nm) between the AL_Post and NAL Pre- training of the extensors and flexors knee.

\begin{tabular}{|c|c|c|c|c|c|c|c|c|}
\hline $\begin{array}{l}\text { Contractions } \\
\text { Modes }\end{array}$ & AL_Pre & NAL_Post & Dif.(\%) & P Valor & AL_Pre & NAL_Post & Diff.(\%) & P Valor \\
\hline Con_30\%/s & $238.4 \pm 48.7$ & $212.2 \pm 46.7$ & $11 \%$ & $<0.05$ & $128.3 \pm 25.1$ & $134.2 \pm 23.7$ & $4 \%$ & 0.25 \\
\hline Con_120\%/s & $173.4 \pm 44.2$ & $161.3 \pm 30.5$ & $7 \%$ & 0.23 & $101.6 \pm 20.7$ & $111.4 \pm 21.6$ & $9 \%$ & $<0.05$ \\
\hline Ecc_120\%/s & $253.2 \pm 93.3$ & $263.4 \pm 59.4$ & $4 \%$ & 0.55 & $138.6 \pm 30.3$ & $172.8 \pm 30.4$ & $20 \%$ & $<0.01$ \\
\hline
\end{tabular}

PTA = Peak torque average; $\mathrm{Nm}=$ Newton. metro; Con = concentric; Ecc = eccentric; $\mathrm{AL}=$ affected limb; $\mathrm{NAL}=$ non affected limb; $\mathrm{MPT}=$ mean peak torque; Diff = difference. $\mathrm{t}$ Student (independent) test.

Table 2. Comparison of the averages of functional tests pre and post-isokinetic eccentric training of the extensors and flexors knee.

\begin{tabular}{|c|c|c|c|c|c|c|}
\hline Hop kinds & \multicolumn{3}{|c|}{ Pre-training } & \multicolumn{3}{|c|}{ Post-training } \\
\hline Single hop (m) & $1.71 \pm 0.29$ & $1.90 \pm 0.20$ & $<0.01 \neq$ & $1.84 \pm 0.21$ & $1.98 \pm 0.19$ & $<0.01 \neq$ \\
\hline Triple hop (m) & $5.36 \pm 0.81$ & $5.83 \pm 0.63$ & $<0.01 \neq$ & $5.63 \pm 0.68$ & $5.97 \pm 0.63$ & $<0.01 \neq$ \\
\hline Crossover hop (s) & $2.61 \pm 0.59$ & $2.44 \pm 0.48$ & $0.06 \neq$ & $2.21 \pm 0.37$ & $2.16 \pm 0.27$ & $0.23 \neq$ \\
\hline \multirow{2}{*}{ Figure-8 hop (s) } & \multicolumn{3}{|c|}{$\mathrm{AL}$} & \multicolumn{3}{|c|}{ NAL } \\
\hline & Pre-training & Post-training & P Valor & Pre-training & Post-training & P Valor \\
\hline Single hop (m) & $1.71 \pm 0.29$ & $1.84 \pm 0.21$ & $<0.05 \dagger$ & $1.90 \pm 0.20$ & $1.98 \pm 0.19$ & $0.06+$ \\
\hline Triple hop (m) & $5.36 \pm 0.81$ & $5.63 \pm 0.68$ & $<0.05 t$ & $5.83 \pm 0.63$ & $5.97 \pm 0.63$ & $0.13+$ \\
\hline
\end{tabular}

$\mathrm{m}=$ meter; $\mathrm{s}=$ second. $\mathrm{t}$ Student independent $(\ddagger)$ and paired $(\dagger)$ tests.

Also showed a significant increase in performance in all tests conducted ( $\mathrm{SH}$ and $\mathrm{TH}: \mathrm{P}<0.05 ; \mathrm{CH}$ and $\mathrm{F} 8 \mathrm{H}: \mathrm{P}<0.01$ ) in the $\mathrm{AL}$ and in the $\mathrm{CH}(\mathrm{P}<0.05)$ and $\mathrm{F} 8 \mathrm{H}(\mathrm{P}<0.01)$ in the $\mathrm{NAL}$, when comparing the pre- and post-training (intra-limb) means.

A significant improvement in $\mathrm{CH}$ and $\mathrm{F} 8 \mathrm{H}$ performance occurred in the $A L(P<0.05)$ when comparing the pre-training NAL versus post-training AL values.

The correlations (MPT versus functional tests) regarding the knee extensors and flexors were mostly weak $(r<0.3)$ in the pre- and post-training, in the $A L$ and NAL. However, the correlations for the knee extensors were moderate $(0.31<r<0.6)$ and strong $(0.61<r<0.9)$ in the: $\mathrm{SH}$ (pre- and post-training), in the $\mathrm{AL}$ and $\mathrm{NAL}$; $\mathrm{TH}$ (all pre-training comparisons, some post-training $\mathrm{AL}$ comparisons and in the concentric mode at $120 \% \mathrm{~s}$ in the pre-training NAL); $\mathrm{CH}$ (concentric and eccentric modes at $30 \% \mathrm{~s}$ in the post-training $\mathrm{AL}$, in the concentric mode at $30 \%$ s and in the eccentric mode at 30 and $120 \%$ s the pre-training) in NAL; and F8H (concentric and eccentric modes at 30 and $120 \%$ s) in the $\mathrm{AL}$.

The correlations regarding the knee flexors were moderate $(0.31<\mathrm{r}<0.6)$ in the $\mathrm{SH}$ : concentric at $120 \%$ s, pre-training; concentric at $30 \%$ s and $120 \%$ s and eccentric at $120 \%$, in the post-training $A L$ and eccentric at 30 and $120 \%$ in the pre-training NAL; TH: isometric and eccentric at $30 \%$ s, pre-training; concentric at 30 and $120 \%$ s in the post-training $\mathrm{AL}$ and in the concentric and eccentric at 30 and $120 \%$ s in the pre-training $\mathrm{AL}$; and $\mathrm{F} 8 \mathrm{H}$ : eccentric at $120 \%$ s pre-training, in the concentric at 30 and $120 \%$ in the post-training $\mathrm{AL}$ and in the isometric and concentric at $30 \%$ s and eccentric at 30 and $120 \%$ s in the post-training NAL (Table 3).

\section{DISCUSSION}

\section{Eccentric Isokinetic Training}

The deficit in pre-training AL extensor torque shown in all tested modes and speeds may be attributed to two factors: 1) decline in gamma motor neuron activation, resulting in efferent la attenuation, leading to quadriceps weakness and dyskinesia, after ACL rupture ${ }^{14}$; and 2) predominant quadriceps atrophy after $A C L$ reconstruction ${ }^{15}$, which persists for years, with a 10 to $20 \%$ loss of strength, despite the efforts focused on rehabilitation ${ }^{14,16}$.

These results corroborate Keays et al. ${ }^{17}$ because they also found differences (28 and 22\%) when comparing the knee extensor torque inter-members, 6 months after ACL reconstruction, at 60 and 120\%s, respectively. The extensor torque deficit in the AL was expected because the tested sample consisted of subjects with chronic injuries (50.4 \pm 34.9 months), and the longer the injury time is, the greater the impairment will be ${ }^{18}$.

The most significant post-training gains, in both extensor and flexor torque, reached in training mode and speed (Ecc_30\%), demonstrate the principle of specificity introduced by Santos et al. ${ }^{3}$ and Santos et al. ${ }^{6}$ when testing resistance training programs at various modes and speeds. Furthermore, the fact that flexor post-training AL values mostly surpassed the pre-training NAL values was expected because no difference was found when comparing pre-training inter-limbs. However, the increase in flexor torque (Ecc_30 and 120\%) in NAL may be explained by the crossover education effect ${ }^{19,20}$. Unilateral resistance training may activate neural circuits 


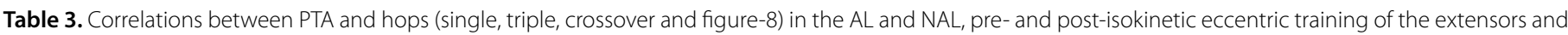
flexors knee.

\begin{tabular}{|c|c|c|c|c|c|c|c|c|c|}
\hline \multirow{3}{*}{$\begin{array}{c}\text { PTA Extensors } \\
\text { X } \\
\text { Hop tests }\end{array}$} & \multicolumn{4}{|c|}{ Limbs } & \multirow{3}{*}{$\begin{array}{c}\text { PTA Flexors } \\
\text { X } \\
\text { Hop tests }\end{array}$} & \multicolumn{4}{|c|}{ Limbs } \\
\hline & \multicolumn{2}{|c|}{$\mathrm{AL}$} & \multicolumn{2}{|c|}{ NLA } & & \multicolumn{2}{|c|}{$A L$} & \multicolumn{2}{|c|}{ NLA } \\
\hline & Pre & Post & Pre & Post & & Pre & Post & Pre & Post \\
\hline Isom X SH & 0.47 & 0.47 & 0.36 & 0.25 & Isom X SH & 0.27 & 0.26 & 0.21 & 0.11 \\
\hline Con $30 \% / \mathrm{s} \times \mathrm{SH}$ & 0.57 & 0.58 & 0.30 & 0.31 & Con $30 \% / s \times$ SH & 0.19 & 0.39 & 0.13 & 0.13 \\
\hline Con $120 \% / \mathrm{s}$ X SH & 0.66 & 0.63 & 0.17 & 0.42 & Con $120 \%$ s X SH & 0.41 & 0.51 & 0.21 & 0.27 \\
\hline $\mathrm{Ecc} 30 \% / \mathrm{s} \times \mathrm{SH}$ & 0.40 & 0.29 & 0.32 & 0.36 & Ecc $30 \%$ s X SH & 0.27 & 0.29 & 0.41 & 0.27 \\
\hline Ecc $120 \% / s \times$ SH & 0.59 & 0.52 & 0.48 & 0.31 & Ecc $120 \% / s \times$ SH & 0.23 & 0.38 & 0.48 & 0.15 \\
\hline Isom XTH & 0.42 & 0.28 & 0.27 & 0.09 & Isom XTH & 0.34 & 0.22 & 0.30 & 0.09 \\
\hline Con $30 \% / \mathrm{s} \times \mathrm{TH}$ & 0.45 & 0.40 & 0.27 & 0.17 & Con $30 \% / \mathrm{s} \times \mathrm{TH}$ & 0.28 & 0.40 & 0.31 & 0.08 \\
\hline Con $120 \% / \mathrm{s}$ X TH & 0.51 & 0.42 & 0.33 & 0.27 & Con $120 \% / \mathrm{s} \times \mathrm{TH}$ & 0.24 & 0.54 & 0.33 & 0.21 \\
\hline Ecc $30 \% / s \times T H$ & 0.40 & 0.08 & 0.22 & 0.23 & Ecc $30 \%$ s X TH & 0.39 & 0.25 & 0.37 & 0.20 \\
\hline Ecc $120 \% / s$ X TH & 0.40 & 0.39 & 0.29 & 0.19 & Ecc $120 \% / s$ X TH & 0.29 & 0.31 & 0.37 & 0.05 \\
\hline Isom XCH & -0.06 & 0.20 & 0.05 & 0.14 & Isom XCH & 0.07 & -0.15 & -0.28 & 0.01 \\
\hline Con 30\% $/$ s_CH & -0.03 & 0.32 & 0.31 & 0.13 & Con 30\%/s_CH & 0.26 & 0.03 & -0.07 & 0.11 \\
\hline Con 120\%/s_CH & -0.20 & 0.14 & 0.26 & 0.06 & Con 120\%/s_CH & -0.02 & 0.08 & 0.14 & -0.01 \\
\hline Exc 30\%/s_CH & 0.18 & 0.38 & 0.48 & 0.09 & Exc $30 \%$ s_CH & -0.12 & 0.26 & -0.19 & 0.06 \\
\hline Exc 120\%s_CH & 0.07 & 0.30 & 0.47 & 0.16 & Exc 120\%s_CH & 0.07 & -0.01 & 0.21 & 0.07 \\
\hline Isom X F8H & -0.27 & 0.14 & -0.19 & -0.02 & Isom X F8H & -0.18 & -0.18 & -0.46 & -0.09 \\
\hline Con $30 \% / s$ X F8H & -0.39 & 0.02 & -0.29 & -0.13 & Con $30 \% / s$ X F8H & -0.28 & -0.35 & -0.42 & -0.10 \\
\hline Con $120 \%$ s X F8H & -0.35 & -0.07 & -0.21 & -0.16 & Con $120 \%$ s X F8H & -0.03 & -0.41 & -0.28 & -0.13 \\
\hline Ecc $30 \% / s$ X F8H & -0.47 & 0.23 & -0.21 & -0.12 & Ecc $30 \%$ s X F8H & -0.40 & -0.11 & -0.56 & -0.18 \\
\hline Ecc $120 \%$ s X F $8 \mathrm{H}$ & -0.34 & -0.11 & -0.14 & -0.11 & Ecc $120 \%$ s X F8H & -0.21 & -0.18 & -0.35 & -0.05 \\
\hline
\end{tabular}

$\mathrm{PTA}=$ peak torque average; $\mathrm{Con}=$ concentric; $\mathrm{Ecc}=$ eccentric; $\mathrm{AL}=$ affected limb; $\mathrm{NAL}=$ non affected limb; $\mathrm{SH}=$ single hop; $\mathrm{TH}=$ triple hop; $\mathrm{CH}=\mathrm{crossover}$ hop; $\mathrm{F} 8 \mathrm{H}=$ figure-8 hop. values of correlation tests (r).

with consequent increase the neural drive (cortico-spinal projections) of untrained muscles and resulting in strength gain, onto the opposite limb.

In general, the training program had the desired effect, since, except in the extension torque Con_30\%s, conversely, the torques were statistically equivalent and even surpassed (Ecc_30\%/s) the pre-training NAL values in the other tested modes and speeds.

Corroborating the study of Tomiya et al. ${ }^{21}$, the current results show that the eccentric resistance training is more efficient in the torque gain than isometric or concentric resistance training at the respective tested speeds $(30 \%$ s and $120 \%$ s).

Gerber et al. ${ }^{22}$, also observed that the extensor PT in the AL of the eccentric exercise group was higher than in the standard rehabilitation group, after $A C L$ reconstruction.

\section{Functional tests}

Before training, the AL versus NAL comparison showed deficits regarding three of the hops tested $(\mathrm{SH}, \mathrm{TH}, \mathrm{F} 8 \mathrm{H})$ in the AL. In the post-training period, deficits regarding the NAL remained, despite the increase in SH and $\mathrm{TH}$ values. The comparison between pre- and post-training values in the AL showed an increase in $\mathrm{SH}$ and $\mathrm{TH}$ (> distance) and $\mathrm{CH}$ and F8H ( $<$ runtime) performance. The decreased $\mathrm{CH}$ and F8H runtime with the NAL may be attributed to the crossed education effect during isokinetic training because the NAL was not trained ${ }^{20,21}$, which was expressed in the functional tests. Lastly, the comparison between the means of functional tests and pre-training NAL versus post-training AL conditions suggests that the Ecc $30^{\circ}$ training improved the performance in the functional tests because it matched the distance reached in the $\mathrm{SH}$ and $\mathrm{TH}$ and decreased the $\mathrm{CH}$ and $\mathrm{F} 8 \mathrm{H}$ runtimes.

Gerber et al. ${ }^{22}$, comparing two protocols of post-ACL reconstruction, observed interaction between extensor PT and SH of the AL showing that eccentric training directly affected the performance in the functional hop test, corroborating, in part, our results.

Santos et al. ${ }^{3}$, also observed a weak correlation $(r<0.5)$ between PT and $\mathrm{SH}$ and a moderate correlation $(0.51 \leq r \leq 0.75)$ between PT and TH for both knee flexors and extensors, when analyzing 20 young and healthy subjects who underwent 6 weeks of eccentric isokinetic training at $30 \% \mathrm{~s}$, especially when performing the test in the same training mode (eccentric) and at a speed similar to that of the task $(120 \%$ s).

Conversely, Vasconcelos et al. ${ }^{12}$ founded strong correlations $(-0.78 \leq$ $r \leq-0.90$ ) with extensor PT, despite having observed weak correlations between knee flexor PT (concentric at 60 and $180 \%$ s) and SH and $\mathrm{CH}$ hop distances, among post-ACL reconstruction subjects using semitendinosus and gracilis graft (ST+Gr). However, these correlations were negative, indicating that these variables moved in opposite directions.

According to several studies ${ }^{23-26}$, hop distance $(\mathrm{SH}, \mathrm{TH}$ and $\mathrm{CH})$ is the most commonly used test to assess functional parameters of return to sports because it measures lower limb power ${ }^{3}$ and expresses the effect of the integrity of neuromuscular control, strength generation capacity and confidence in the limb ${ }^{27}$. However, the evidence is still conflicting on which muscle group is more involved in knee functional activities. It is noteworthy that these correlations were classified from weak to strong (from $r=0.25$ to $r=0.62$ ) for both flexors and extensors in the present study.

Jang et al. ${ }^{5}$ reported that isokinetic strength tests fail to quantify knee functionality because they are an open kinetic chain exercise and therefore do not faithfully reproduce the functional range of motion of the joint. This assertion may partly explain the weak and moderate correlations between isokinetic PT and functional tests found in the present study.

On the other hand, Kollock et al. ${ }^{28}$, analyzing 62 recreational athletes of both sexes, concluded that hop tests alone did not provide enough 
information to make evidence-based decisions about lower extremity strength inisolated muscle groups.

Indeed, the success of ACL reconstruction may be explained mainly by a good joint functionality. This is supported by studies reporting poor functional results, despite satisfactory joint mechanics and vice-versa, according to Anders et al. ${ }^{29}$. Furthermore, Feller and Webster ${ }^{30}$ reported that not only surgical and rehabilitation details but also age and injury and surgery times are involved in knee function, vice-versa to return to sports activities.

Most studies addressing the correlation of PT with functional tests exclusively assess $\mathrm{SH}$, complicating the discussion of data. Although they were recorded by the same examiner, the manual timing of $\mathrm{CH}$ and $\mathrm{F} 8 \mathrm{H}$ tests recorded, may have affected the results for being an examiner-dependent measure.

\section{CONCLUSION}

Although the training program proved effective in knee torque gain and functional hop tests, the expected correlation between these variables was not found. Nevertheless, functional tests are still considered a parameter required to resume the practice of competitive sports.

\section{ACKNOWLEDGEMENT}

À Coordenação de Aperfeiçoamento de Pessoal de Nível Superior (CAPES); Fundação de Amparo à Pesquisa do Estado de São Paulo (FAPESP); Conselho Nacional de Desenvolvimento Científico e Tecnológico (CNPq) e ao Departamento de Educação Física da UFSCar.

All authors declare no potential conflict of interest related to this article.

AUTHORS' CONTRIBUTIONS: Each author made significant individual contributions to this manuscript. HHS (0000-0003-3951-8344)*: creation of the entire research project, data collection, statistical analysis, intellectual concept of the article and drafting of the article; COS (0000-0002-2818-3596)*: data collection and data analysis; CLPM (0000-0003-3488-0619)*: data collection, data analysis; JAB (0000-0003-0951-254X)*: statistical analysis, correction and review of the article; AMFB (0000-0002-1148-7681): statistical analysis, correction and review of the article; TFS (0000-0002-6353-6393)*: correction and review of the article. *ORCID (Open Researcher and Contributor ID).

\section{REFERENCES}

1. Abourezk MN, Ithurburn MP, McNally MP, Thoma MT, Briggs M, Hewett TE, et al. Hamstring strength asymmetry at 3 years after Anterior Cruciate Ligament reconstruction alters knee mechanics during gait and jogging. Am J Sports Med. 2017;45(1):97-105.

2. Büchler L, Regli D, Evangelopoulos DS, Bieri K, Ahmad SS, Krismer A, et al. Functional recovery following primary ACL repair with dynamic intraligamentar stabilization. Knee. 2016;23(3):549-53.

3. Santos HH, Ávila MA, Hanashiro DN, Camargo PR, Salvini TF. The effects of knee extensor eccentric training on functional tests in healthy subjects. Rev Bras Fisioter. 2010;14(4):276-83.

4. Xergia AS, Pappas E, Zampeli F, Georgiou S, Georgoulis AD. Asymmetries in functional hop tests, lower extremity kinematics, and isokinetic strength persist 6 to 9 months following Anterior Cruciate Ligament reconstruction. J Orthop Sports Phys Ther. 2013;43(3):154-16.

5. Jang SH, Kim JG, Ha JK, Wang BG, Yang SJ. Functional performance tests as indicators of returning to sports after Anterior Cruciate Ligament reconstruction. Knee. 2014;21(1):95-101.

6. Santos HH, Hanashiro DN, Ávila MA, Camargo PR, Oliveira AB, Salvini TF. Efeito do treino isocinético excêntrico sobre a razão I/Q do torque e EMGs em sujeitos saudáveis. Rev Bras Med Esporte. 2014;20(3):182-7.

7. Gokeler A, Welling W, Zaffagnini S, Seil R, Padua D. Development of a test battery to enhance safe return to sports after Anterior Cruciate Ligament reconstruction. Knee Surg Sports Traumatol Arthrosc. 2017;25(1):192-9.

8. Gokeler A, Welling W, Benjaminse A, Lemmink K, Seil R, Zaffagnini S. A critical analysis of limb symmetry indices of hop tests in athletes after Anterior Cruciate Ligament reconstruction: a case control study. Orthop Traumatol Surg Res. 2017;103(6):947-51.

9. Phillips N, Benjamin M, Everett T, Van Deursen RWM. Outcome and progression measures in rehabilitation following anterior cruciate ligament injury. Phys Ther Sport. 2000;1(4):106-18.

10. Greenberg EM, Greenberg ET, Ganley TJ, Lawrence JTR. Strength and functional performance recovery after Anterior Cruciate Ligament reconstruction in preadolescent athletes. Sports Health. 2014;6(4):309-12.

11. Beck TW. The importance of a priori sample size estimation in strength and conditioning research. J Strength Cond Res. 2013;27(8):2323-37.

12. Vasconcelos RA, Bevilaqua-Grossi D, Shimano AC, Paccola CAJ, Salvini TF, Prado CL, et al. Análise da correlação entre pico de torque, desempenho funcional e frouxidão ligamentar em indivíduos normais e com reconstrução do ligamento cruzado anterior. Rev Bras Ortop. 2009;44(2):134-42.

13. Albuquerque $\mathrm{PL}$, Quirino MAB, Santos HH, Alves SB. Interferência da prática de atividade física habitual na postura de jovens. Rev Ter Man. 2010;8(37):198-203.

14. Williams GN, Barrance PJ, Snyder-Mackler L, Buchanan TS. Altered quadriceps control in people with Anterior Cruciate Ligament deficiency. Med Sci Sports Exerc. 2004;36(7):1089-97.

15. Grant JA, Mohtadi NG, Maitland ME, Zernicke RF. Comparison of home versus physical therapy-supervised rehabilitation programs after anterior cruciate ligament reconstruction: a randomized clinical trial. Am J Sports Med. 2005;33(9):1288-97.
16. Becker R, Karlssom J. The role or muscle function after Anterior Cruciate Ligament rupture and treatment. Knee Surg Sports Traumatol Arthrosc. 2018;26(2):355-7.

17. Keays SL, Bullock-Saxton JE, Keays AC. Strength and function before and after Anterior Cruciate Ligament reconstruction. Clin Orthop Relat Res. 2000;(373):174-83.

18. Gerber JP, Marcus RL, Dibble LE, Greis PE, Burks RT, LaStayo PC. Effects of early progressive eccentric exercise on muscle structure after Anterior Cruciate Ligament reconstruction. J Bone Joint Surg Am 2007:89(3):559-70.

19. Zhou S. Chronic neural adaptations to unilateral exercise: mechanisms of cross education. Exerc Sport Sci Rev. 2000;28(4):177-84.

20. Lee M, Carroll TJ. Cross education: possible mechanisms for the contralateral effects of unilateral resistance training. Sports Med. 2007;37(1):1-14

21. Tomiya A, Aizawa T, Nagatomi R, Sensui H, Kokubun S. Myofibers Express IL-6 after eccentric exercise. Am J Sports Med. 2004;32(2):503-8.

22. Gerber JP, Marcus RL, Dibble LE, Greis PE, Burks RT, LaStayo PC. Safety, feasibility, and efficacy of negative work exercise via eccentric muscle activity following Anterior Cruciate Ligament reconstruction. J Orthop Sports Phys Ther. 2007;37(1):10-8.

23. Augustsson J, Thomeé R, Karlsson J. Ability of a new hop test to determine functional deficits after anterior cruciate ligament reconstruction. Knee Surg Sports Traumatol Arthrosc. 2004;12(5):350-6.

24. Holm I, Fosdahl MA, Friis A, Risberg MA, Myklebust G, Steen H. Effect of neuromuscular training on proprioception, balance, muscle strength, and lower limb function in female team handball players. Clin J Sport Med. 2004;14(2):88-94.

25. Pollet V, Barrat D, Meirhaeghe E, Vaes $\mathrm{P}$, Handelberg F. The role of the Rolimeter in quantifying knee instability compared to the functional outcome of ACL-reconstructed versus conservatively-treated knees. Knee Surg Sports Traumatol Arthrosc. 2005;13(1):12-8.

26. O'Donnell S, Thomas SG, Marks P. Improving the sensitivity of the hop index in patients with an ACL deficient knee by transforming the hop distance scores. BMC Musculoskel Disord. 2006;7:9

27. Reid A, Birmingham TB, Stratford PW, Alcock GK, Giffin JR. Hop testing provides a reliable and valid outcome measure during rehabilitation after Anterior Cruciate Ligament reconstruction. Phys Ther 2007;87(3):337-49

28. Kollock R, Van Lunen BL, Ringleb SI, Oñate JA. Measures of functional performance and their association with hip and tigh strength. J Athl Train. 2015;50(1):14-22.

29. Anders JO, Venbrocks RA, Weinberg M. Proprioceptive skills and functional outcome after anterior cruciate ligament reconstruction with a bone-tendon-bone graft. Int Orthop. 2008;32(5):627-33.

30. Feller JA, Webster KE. A randomized comparison of patellar tendon and hamstrings tendon Anterior Cruciate Ligament reconstruction. Am J Sports Med. 2003;31(4):564-73. 